\title{
Booklets as a Community Based Education Related To Child Development for Kotaanyar Community, Probolinggo
}

\author{
Lailatul Fitriyah¹, Zaini Gunawan², Tristan Rokhmawan ${ }^{3}$ \\ Faculty of Islamic Education Nurul Jadid University Paiton ${ }^{1,2}$, East Java, Indonesia, \\ Indonesian Language \& Literature Education PGRI Wiranegara University \\ Pasuruan, East Java, Indonesia ${ }^{3}$ \\ lailatulfitriyah15.lf@gmail.com, lekgun2@gmail.com, \\ tristanrokhmawan19890821@gmail.com
}

Article History:

Received: June $12^{\text {th, }} 2020$

Revised: August $13^{\text {th }} 2020$

Accepted: September 30th, 2020

\begin{abstract}
In the context of the availability of literacy sources about early childhood development, the people of Kotaanyar District, Probolinggo Regency are constrained by limited access and understanding. In this case, the limited access is the limitation in finding main literacy sources such as books and online literacy content. The limitation of knowledge in this case is their difficulty (parents of early childhood) to understand the content that contains scientific and technical concepts regarding the information on children's development. This is due to the low participation rate in taking education in this area. With this problem, researchers conducted research \& development of booklets with stimulus content for early childhood growth and development, which were made in such a way as to be completed with pictures and by using simple exposures, direct practice, and local language. The content developed is divided according to developmental age and children's growth stages, ages 0-12 months, 12-24 months, 24-36 months, 3648 months, pre-school age 48-60 months. The development of stimulation content is divided based on general information on growth and developmental aspects, including aspects of motoric physical development, cognitive development aspects, aspects of language development, and social-emotional development aspects. As a basis for development, we use some references related to children's accumulation strategies from several books; the rest we add stimulus content based on child development problems found in a typical and contextual manner in the Kotaanyar District community. Presentation in bilingual form is needed to be understood by the local community, who mostly speak the Madura Pendalungan area (slightly different from the language of the island Madurese / origin Madurese). Therefore, after the content and illustration development stage, the researcher translated the booklet into the Madurese Pendalungan language. This is solely done to facilitate understanding of the local community and facilitate early childhood education coaches/socializers to explain in the local language. Finally, we need to package a
\end{abstract}


booklet with an attractive and illustrated layout to illustrate the child's stimulation activity.

Keywords: Stimulation book, early childhood, development

\section{INTRODUCTION}

In this paper, we will combine the approach of thinking from the direction of community-based education/socialization and regional languages for the benefit of non-formal education. So with that, we came up with the idea of the formulation of a booklet design containing guidelines for the stimulation of children needed for a mother in presenting local language and contextual content.

The need for information related to the stimulation of growth and early childhood development is an important point to ensure the continuity of life at the beginning of children's golden age. This period is the best stage to optimize the child's development. In this early life, the nerve connections as a basis for growth are well developed, and therefore stimulation to hone children's abilities is very important to note. This means that at that age, the child's brain must get optimal stimulation. If the child does not get the maximum stimulation, then all the child's growth and development, both physically and mentally, will not develop properly. A very strategic role in optimizing early childhood development is the role of parents. An important period in child development is the first five years of an individual's life; that's the golden period in life!

As a reference for previous research, several studies are relevant to this research. First, a course entitled The Use of Visual Communication Media as a Communication Strategy in Socializing Adolescent Reproductive Health. They are written by Esty Wulandari, 2013, in an article in the UNS FSSR Ethnographic Journal. Finding out about sexuality issues that are considered taboo by the community can be informed to adolescents by conveying correct and clear messages using visual communication design media that attracts socialization. Second, the research entitled The Role of Counseling Using Booklets on Changes in Knowledge and Attitudes of Undernourished Mothers of Toddlers, written by Salimar et al., 2009, in the form of an article in The Journal of Nutrition and Food Research. Finding booklets is proven to be one of the supporting facilities to increase mothers' knowledge and attitudes in overcoming malnutrition under five. Third, the research entitled Counseling of Mother's Attitudes in Providing Toilet Training to Children and written by Musfiroh \& Wisudaningtyas, 2014, in the form of the Society's Kesehatan Journal. Finds that counseling on mothers' attitudes in providing toilet training to children under five is an effect of counseling.

The availability of information regarding early childhood development and growth is an important matter that must be pursued, especially in the current digital era, 
making it easier for people to access information easily through more innovative information content. However, not all information regarding early childhood growth and development can be accessed easily, especially in areas with low public education levels. Both printed and digital access is no longer easy to reach because of several factors: understanding literacy content and language use. Lack of general knowledge regarding the information on the development and growth of early childhood is also inseparable from the lack of literacy distribution related to child growth and development. As is the case with the people of Kotaanyar District who have limited literacy sources that can provide information on children's development and growth, they need access and understanding related to information content that is clear and easy to understand.

In general, information regarding children's growth and development has been widely spread in health centers, both the Village Health Center (village level) to the Community Health Center at the District level. However, with the background of the people of Kotaanyar District, most of whom have a low level of education, the existing literacy sources are less than optimal. In this case, the researchers concluded the results of pre-research observations that: the people of Kotaanyar District need a form of development of alliteration sources that contain information about handling child development in a simple, practical-casuistic appearance, with easy-to-understand explanations, and contain their local language, namely the Madurese Pendalungan language.

\section{METHOD}

The stages of this research were arranged by following the suggestion of a 4-D development model by S. Thiagarajan, D. S. Semmel, \& M. I. Semmel (1974). The researcher determined the research stages as follows: 1) The defining stage of development. At this stage the researchers conducted: preliminary research, concrete problems and needs analysis, analysis of early childhood development concepts both theoretically and in the application, and analysis of research concepts and development of booklets/leaflets as a community-based educational tool. 2) Research and product design stage. At this stage the researcher does: design research \& development, design the content of the booklet/leaflet, and create the embodiment of the booklet/leaflet. 3) Product development stage. At this stage the researchers carried out: production/preparation of booklets/leaflets, submitting ISBN and IPR for booklets/leaflets, and printing booklets / leaflets. 4) Product dissemination stage \& research results. At this stage the researchers carried out: disseminating booklets / leaflets, disseminating the use of booklets / leaflets, and disseminating research and development reports.

The location for the dissemination and socialization of the product was carried out in Kotaanyar District, Probolinggo, East Java. The target community subjects are mothers, especially those who have children aged 1 to 6 years. The location for the 
dissemination and socialization of the product was carried out in Kotaanyar District, Probolinggo, East Java. The target community subjects are mothers, especially those who have children aged 1 to 6 years.

\section{RESULTS AND DISCUSSION} Preliminary Study and Plans

From the preliminary study results, the researchers found that early childhood in Kotaanyar District, Probolinggo Regency, experienced various problems in terms of development. From the analysis of 27 children spread across Kotaanyar District, it was found that at least 8 physical motor problems, 9 cognitive problems, 11 language problems, and 11 socio-emotional problems were found.

The details of preliminary research data regarding these child development problems can be seen in detail as follows:

Age 3 to 5 years ( 7 people) : 1 . Physical motor has not been able to stand on one lega ; 2 . has not been able to do a grip motion ; 3 . have not been able to make vertical, horizontal, left / right, oblique left / right, and circle Lines ; 4 . has not been able to coordinate the eyes and hands to perform complex movements; 5 . have not been able to express themselves by creating art using various media ; 6 . Cognitive has not been able to recognize cause and effect symptoms related to sel ; 7. Able to sort objects by size and Colo ; 8. recognize the symbols of numbers ; 9. The language has not been able to understand the two commands given simultaneously ; 10. express feelings with adjectives ; 11 . express opinions ; 12 . state the reasons for something desired or disagree ; 13. retelling stories / fairy tales that have been heard ; 14 . participate in conversations ; 15 . Social-emotional has not been able to show an independent attitude in choosing Activities; 16. control feelings ; 17. proud of your own Works ; 18. keep yourself from the Environment ; 19. show enthusiasm in Activities ; 20. obey the rules in a Games.

Age $5 \mathrm{~s} / \mathrm{d} 6$ years (20 people) : 1 . Physical motor has not been able to do selfcleaning Activities ; 2. draw according to the Ida ; 3 . Express yourself through detailed drawing gestures ; 4. Cognitive has not been able to show exploratory / probing Activities ; 5 . solve simple problems in everyday life in a flexible and socially acceptable manner; 6 . apply knowledge or experience in a new context ; 7 . Show creativity in solving problem ; 8. compile an activity Plan ; 9. Classify objects based on color, shape and size in 3 variations ; 10 . Language has not been able to repeat more complex sentences ; 11 . answer complex questions ; 12 . communicate verbally, have vocabulary, and recognize symbols in preparation for reading, writing and counting; 13 . compose simple sentences in a complete structure ; 14 . continue some of the stories / fairy tales that were heard ; 15 . Social-emotional has not been able to show the ability to adapt to the situation; 16 . organize yourself ; 17. Know the feelings of friends and respond appropriately ; 18. show tolerance ; 19. express emotions according to conditions. 
Therefore, in this study, researchers developed facilities and sources of information to support community-based education programs in the form of booklets. The booklet referred to in the explanation above contains various sources of information and education related to child development problems and their solutions. In addition to focusing on problems found in the field, researchers develop educational content to more complex forms of early childhood development problems.

The bilingual presentation is expected to make it easier for the targeted community to understand the booklet content. With these considerations, the booklet from the development of this research was developed in Indonesian and Madurese.

Regarding the literary style, the people of Kotaanyar District need special direction in encouraging their willingness to study the content of this community-based education program. For this reason, the booklets that have been developed by researchers will be placed in locations where the community, especially housewives, or those with early childhood usually gather.

\section{Stimulation Booklet Content Development}

The content developed is divided according to developmental age and child growth stages, ages 0-12 months, 12-24 months, 24-36 months, 36-48 months, pre-school age 48-60 months. The development of stimulation content is divided based on general information on growth and developmental aspects including: aspects of physical motor development, aspects of cognitive development, aspects of language development, aspects of social emotional development. As a basis for development, the main reference was developed from the book on smart mother in childcare by dr. Anastasia ratnaningsih, Sp.A (Ratnaningsih, 2017) was then reprocessed to add stimulus content and child development problems found in a typical and contextual manner in the Kotaanyar District community.

Optimizing children's development can be done from an early age, because at this time early childhood is in the golden age phase, which ranges from 0-8 years of age. Early childhood can also be interpreted as a child who is vulnerable to $0-8$ years old and a figure who is undergoing a process of rapid development and is fundamental for the next life. Law of the Republic of Indonesia number 20 of 2003 concerning the national education system explains that early childhood education is held for children from birth to 6 years and is not a prerequisite for attending basic Education (Sujiono, 2009)

From the description above, we can conclude that early childhood is a period of goden age where at this time children are experiencing development both physically and motor, social, emotional, cognitive, language and moral (Pratiwi, 2017). 
Child development is also influenced by stimulation and psychological. Stimulation / stimulation, especially in the family, for example by providing toys, child socialization, involvement of mothers and other family members will influence the child in achieving optimal development. Conclusion: a child whose existence the parents do not want or who is always feeling depressed will experience growth and development (Chamidah, 2009). Four risk factors affect children's development in developing countries, namely severe chronic malnutrition, inadequate early stimulation, iodine deficiency, and iron deficiency anemia (Hati \& Lestari, 2016).

One of the important risk factors associated with mother-child interaction is early stimulator (Suryawan, 2012). The combination of positive mother-child interaction, physical exercise and early stimulation will improve children's motor development (Chiarello \& Palisano, 1998). Research in Indonesia also shows the same relationship, stimulating optimal growth and development in children will help achieve children's cognitive development well (Warsito et al., 2012).

\section{Stimulate the development of physical motor aspects}

Physical development is the growth or change that occurs in the shape or size of the human body, the growth process has a cephalocaudal principle, which starts from the head to the feet and also the proximodistal principle, namely that growth starts from the middle such as the body towards the edges of the body such as the hands and feet. Meanwhile motor development is a change in the ability to perform movements. Physical development supports children's motor development, and motor development supports children's learning success. As physical development begins to mature, motor development can develop and begin to be wellcoordinated. At this time, children usually start to do excessive movement and activity. Therefore at this time it is very good to train their motor development by doing coordinated body movements to bring about flexibility and balance in children.

\section{Stimulate the development of cognitive aspects}

Cognitive development begins in the prenatal phase, which means that nerve cells begin to develop in the womb. However, this development is only limited to the development of the structure and maturation of nerve cells. Brain cells develop and process in the post-natal phase's cognitive domain, especially starting at around 5 months of age when the child's sensory abilities begin to mature. Before the age of 5 months, the development of reflex abilities is regulated by the nervous system in accordance with the stimuli received by the baby. Cognitive development is related to the thinking and intellectual development of children. In this phase the child begins to learn to practice thinking skills in solving simple problems and children need to have the ability to find ways to solve them. 
Therefore, it is very important to continue to stimulate children's cognitive development to support children's learning processes.

\section{Stimulate the development of language aspects}

Language skills are one of the characteristics of children's intelligence. language skills are different for each child. some have good quality in language, but some have low proficiency. Language is a means of communicating with the Environment. Through language, children can express their feelings. This is very important because children's language supports children's learning processes about many things. Especially in learning to communicate and respond to what is given by the Environment. Children's language skills will continue to develop according to the stage of their age, but actually entering the age of 1 year, the child's brain is ready to process words through their sensory hearing. When the children are 2 years old, they begin to listen a lot through interactions and store new vocabulary through what they hear. And by the time he is 3 years old, the children's language increases closer to adult language's complete structure. Furthermore, entering the age of 4-6 years, along with the development of children's intelligence skills, children's language skills also develop rapidly like adults in general.

\section{Stimulate the development of the social and emotional aspects}

Emotional social development is children's ability and skills to develop knowledge to learn to express both positive and negative emotions related to interactions with their surrounding Environment by exploring and responding to what is around them. In short, social and emotional development includes the child's ability to express emotions and respond to everything in the surrounding Environment. This social emotional development aims to make children have good self-management skills such as self-confidence, social skills, and control emotions. The stimulation of social emotional development in children can be provided by teachers, parents and the Environment by inviting children to learn to interact and respond to their Environment.

\section{Language Presentation}

Presentation in bilingual form is needed so that it can be understood by the local community who mostly speak the Madura Pendalungan area (slightly different from the language of the island Madurese). Therefore, after the content and illustration development stage, the researcher translated the booklet into Madurese Pendalungan language. This is solely done to facilitate understanding 
the local community and make it easier for early childhood education cadres to explain in the local language. Here's an overview of how we present bilingual content in the booklet.

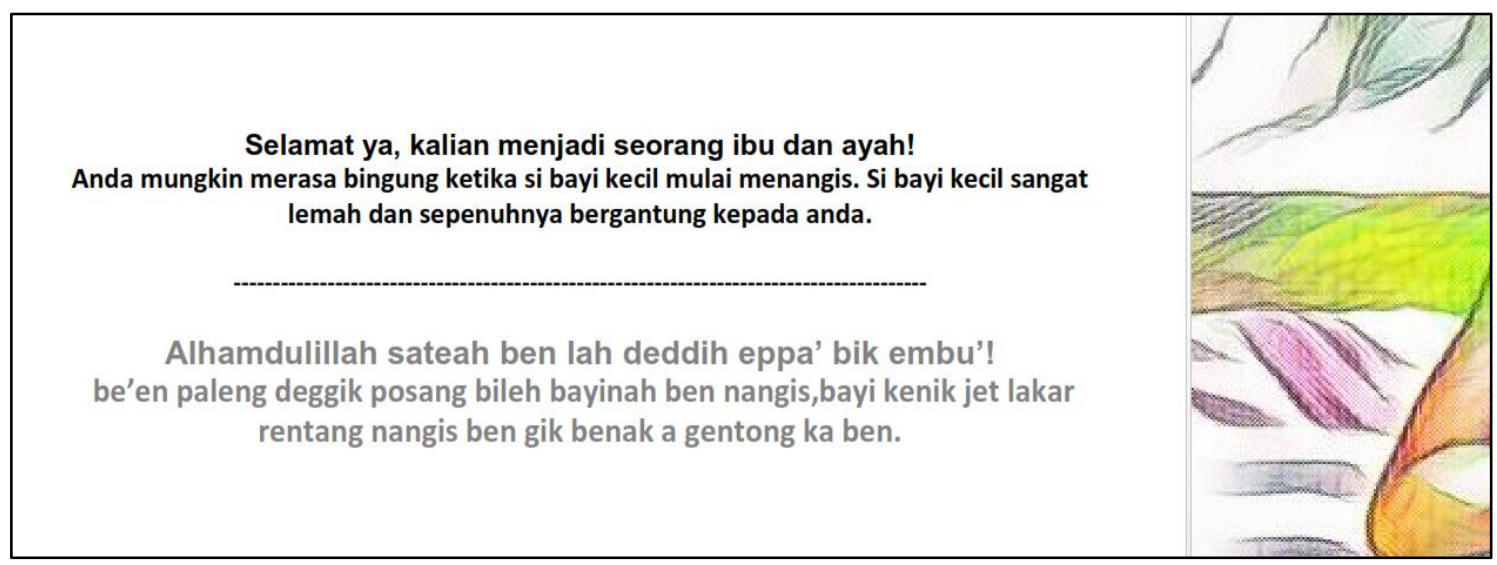

\section{Madurese Pendalungan Language}

The definition of Pendalungan began to emerge in the early 2000s. The term Pendalungan is a culture resulting from acculturation that occurs due to the acculturation process of several cultures that occur in the horseshoe area. Pendalungan can be simplified by calling it a new generation of mixed MadureseJavanese marriages and a mixture of Madurese-Javanese cultures (a mixture of both genetically and culturally) (Prasisko, 2015; Sutarto, 2006)

Pasuruan to Banyuwangi are Pendalungan areas. The Pendalungan community is a community that has historically migrated from the northern part of East Java (called the 'arek' community: Mojokerto, Sidoarjo, Surabaya, and Gresik), central Java (called the Mataraman community), and Madura, towards the expansion area. agricultural areas ranging from Pasuruan to Banyuwangi. The expansion of this region has occurred for a long time until now. This is evident from the many plantation companies that have been established since colonial times in the Pendalungan area. Among them are national commodity plantations such as sugar cane, tea, coffee, tobacco, and various other commodities. Apart from the migration factor caused by regional development, the migration of the Pendalungan community was also caused by the existence of "exile" or "forced labor placement" practitioners during the colonial era, where many people from various regions in Indonesia were exiled to the Pendalungan area to be forced to work on the colonial government plantations (Hadi, 2017)

In terms of language development, the Pendalungan community developed a language variant of the Madurese base language which is influenced by the vocabulary of Javanese Arek and Mataraman; language acculturation occurs. Apart from the factors of migration, history, and regional expansion, language acculturation is also caused by the awareness of the people who in fact speak 
Madurese to adapt to the vocabulary in Javanese culture. Even in more modern times, the language of Pendalungan is still developing according to Indonesian. The development of the Pendalungan language has occurred to date solely fulfilling the needs of the times and intercultural communication in Pendalungan, considering that apart from being dominated by the Madurese custom, Pendalungan also has many other cultures such as Javanese, Arabic, Chinese, and other cultures from outside Java.

\section{National and Regional Language Bilingual Function}

Practical bilingualism is related to code switching behavior. Humans at one time speak 2 or more languages interchangeably. Code switching is a transition event from one code to another. In this research, information is presented in two languages or translated to explain information in different languages. The function of code switching based on several types of research is to convince, familiarize, invite, convey certain intentions, provide advice, and remind (Pristiwati, 2010; Wulansari, 2013). While the function of coding (or language) in the context of the development of this research is to strengthen the purpose of conveying information and adjusting the understanding of language to the readers / information target.

\section{Booklet Content Development Results}

The content booklet for 0 to 12 months consists of the following 15 topics: 1) Have new Children, 2) First breast Milk, 3) Wrapping swaddling, 4) Baby "octopus" outfit, 5) Drying the bab, 6) Urinating and defecating, 7) Express breastmilk, 8) Bath the bab, 9) Kissing the bab, 10) MPASI (complementary foods of breastmilk), 11) What food should be given first time?, 12) Stage of baby motion, 13) The growth of baby teeth, 14) Crawl, and 15) Walk. Here's what this section looks like on the booklet cover:

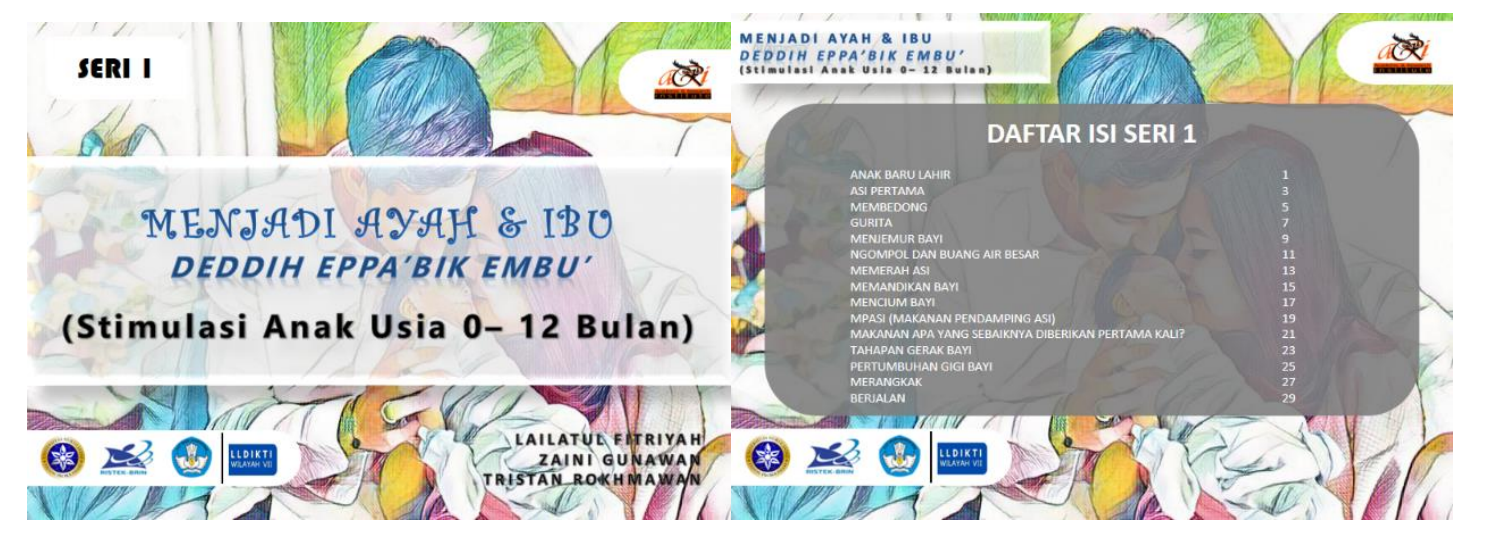

The content booklet for 12 to 24 months consists of the following 15 topics: 1 ) Practice speaking with fun, 2) Sing, 3) Respond to your little one's babbling, 4) Father and mother avoid speaking 2 languages, 5) Accompany your little one 
watching children's film, 6) playing together with child, 7) Benefits of play for babies, 8) Emotions in babies, 9) How to introduce emotions to your little One, 10) First aid if the child falls, 11) Get to know activities that mothers and fathers can do with their little Jones, 12) Benefits of play for Children, 13) Keep your little one's hands clean, 14) Can children do scribble? (or doodling), 15) Train your little one's Independence, 15) Teaching children to socialize. Here's what this section looks like on the booklet cover:

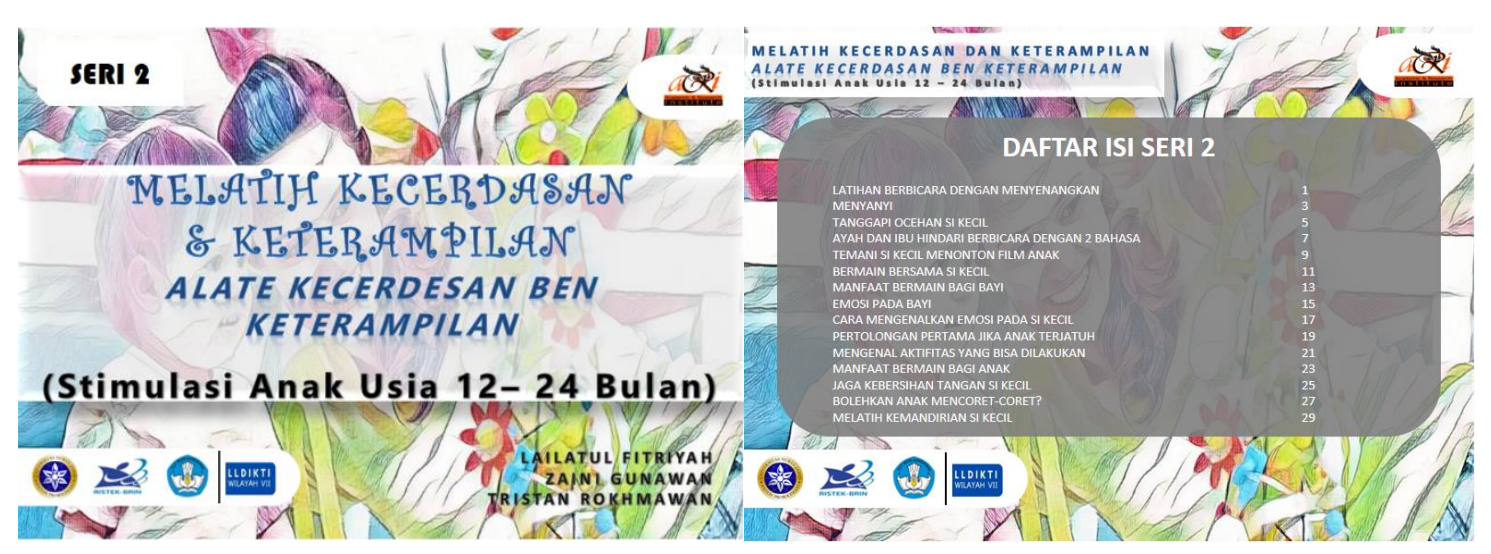

The content booklet for 24 to 36 months consists of the following 15 topics: 1) Toilet training, 2) Sing, 3) practice language skills, 4) Train children's positive behavior, 5) Increase the child's immune System, 6) Teaches simple hospitality and courtesy, 7) So that your little one likes to help from an early Cage, 8) Why are young children cranky?, 9) Promote trust in Children, 10) Do you know?, 11) What if the child likes spanking?, 12) Teach children to apologia, 13) Teach children to eat alon, 14) Teach children to be willing to share with others, 15) Free time with Children, 16) Overcoming tantrum Children, 17) First aid when the child falls. Here's what this section looks like on the booklet cover:

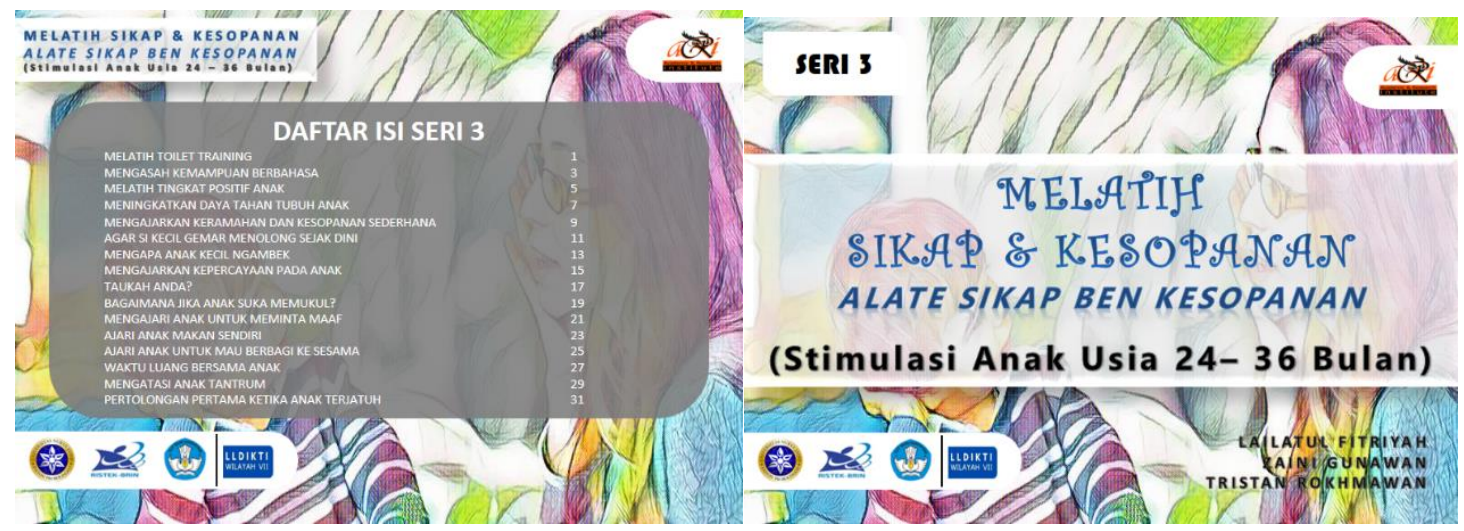

The content booklet for pre-school age 48- 60 months consists of the following 15 topics: 1) Characteristics of children ready to enter the playgroup stage, 2) How to 
choose play group schools for Children, 3) The development of a 3 year old preschooler, 4) Development of pre-school children aged 4 years, 5) Development of pre-school children aged 5 years, 6) Teaching children discipline, 7) Foods that help increase children's focus in their learning environment, 8) Train children's motor skills, 9) Train children's cognitive abilities, 10) Train children's social emotional skills, 11) Train creativity in Children, 12) Hone moral and religious skills. Here's what this section looks like on the booklet cover:

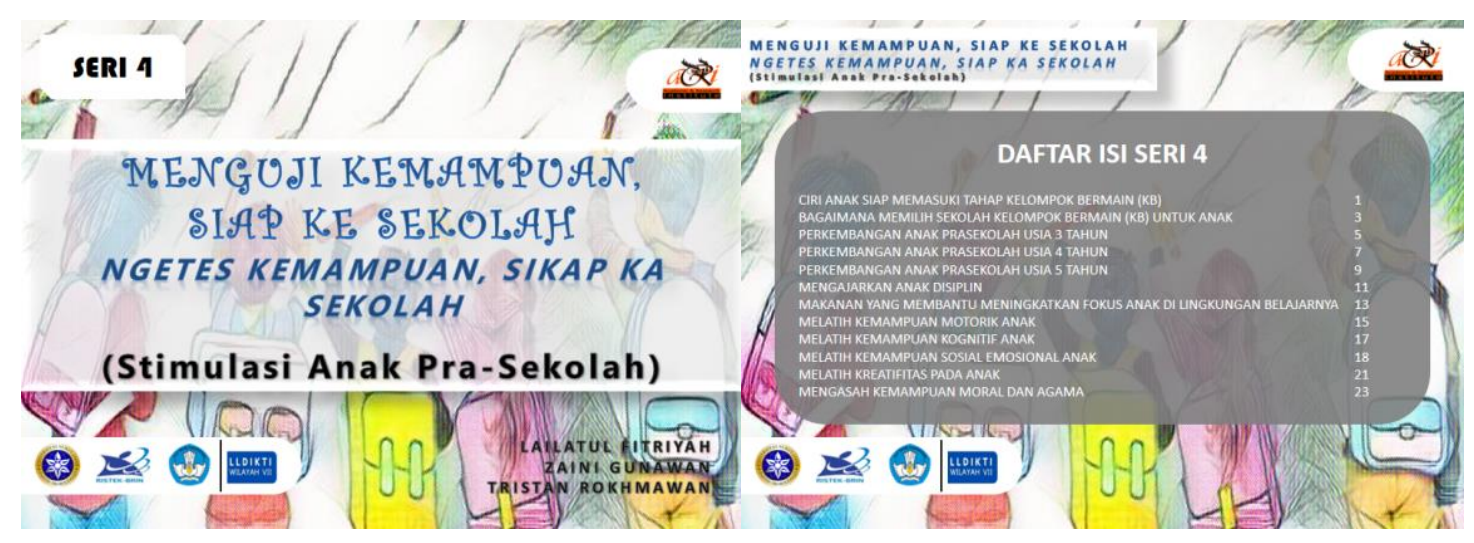

The content mentioned above is presented in a combination of illustrations and bilingual texts in Indonesian and regional languages. I uploaded the content presentation in tabular form as the basis for my research data on the Researchgate web page:

https://www.researchgate.net/publication/344264325_Stimulation_Booklet_Cont ent_Development_in_table (Fitriyah et al., n.d.)

\section{CONCLUSION}

With the above discussion, we have completed the development of booklet content related to efforts to stimulate early childhood growth and development, whose language and context are adapted to the culture of the people of Kotaanyar, Probolinggo Regency. We can also conclude that the development of booklet content using multilingual Indonesian and regional languages is possible to develop booklets as a means of community-based education. It is hoped that the booklet will be easily understood by the reading public when it has regional language qualifications and a lack of quality education.

In the end, developing the content design for this booklet will form the basis for further development of the booklet. The booklets that we will develop are 4 booklet manuscripts divided according to developmental age and children's growth stages, ages 0-12 months, 12-24 months, 24-36 months, 36-48 months, 
pre-school age 48-60. months. The development of stimulation content is divided based on general information on growth and developmental aspects, including aspects of motoric physical development, cognitive development aspects, aspects of language development, and aspects of social emotional development.

In conclusion, I think it is appropriate for me to make a claim statement that the development of this content will become the embryo of a booklet that has many benefits for the community.

\section{ACKNOWLEDGMENTS}

This article was created to be part of a scientific publication on the research entitled : R\&D of Booklets As A Community Based Education Related To Child Development In Kotaanyar, Probolinggo District, Indonesia. This research was funded under the 2020 Beginner Lecturer Research scheme by the Ministry of Research \& Technology / the National Research \& Innovation Agency of the Republic of Indonesia. The research contract number is NJ-T06 / 0152 / A.2 / 09.2020 on the decision of the Director General of Research and Development Strengthening No. 7 / E / KPT / 2019 concerning Acceptance of Research Funding in Universities for the 2019 fiscal year.

The writers in this work contribute according to their fields. Lailatul Fitriyah is the initiator as well as the head of research. Zaini Gunawan served as a research member who took part in carrying out field tasks and coordinating with various related parties. Tristan Rokhmawan is a researcher from outside the main research institution, who then gets the task of being a language director according to his professionalism.

\section{REFERENCES}

Chamidah, A. N. (2009). DETEKSI DINI GANGGUAN PERTUMBUHAN DAN PERKEMBANGAN ANAK. Jurnal Pendidikan Khusus, 4(3), 8. https://doi.org/10.21831/jpk.v4i3.789

Chiarello, L. A., \& Palisano, R. J. (1998). Investigation of the Effects of a Model of Physical Therapy on Mother-Child Interactions and the Motor Behaviors of Children With Motor Delay. Physical Therapy, 78(2), 180-194. https://doi.org/10.1093/ptj/78.2.180

Fitriyah, L., Rokhmawan, T., \& Gunawan, Z. (n.d.). Stimulation Booklet Content Development (in table). Researchgate. https://www.researchgate.net/publication/344264325_Stimulation_Bookl et_Content_Development_in_table

Hadi, Y. Setiyo. (2017). Asal Usul Pandhalungan. Salam Nusantara. 
Hati, F. S., \& Lestari, P. (2016). Pengaruh Pemberian Stimulasi pada Perkembangan Anak Usia 12-36 Bulan di Kecamatan Sedayu, Bantul. Jurnal Ners dan Kebidanan Indonesia, 4(1), 44. https://doi.org/10.21927/jnki.2016.4(1).4448

Prasisko, Y. G. (2015). Blandongan: Perebutan Kuasa Budaya Masyarakat Jawa dan Madura. LPRIS.

Pratiwi, W. (2017). KONSEP BERMAIN PADA ANAK USIA DINI. Tadbir: Jurnal Manajemen Pendidikan Islam, 5(2), 106-117.

Pristiwati, R. (2010). KEEFEKTIFAN PENGGUNAAN ALIH KODE DAN CAMPUR KODE DALAM WACANA DAKWAH AGAMA ISLAM KAUM WANITA. LINGUA, 6(1), 10.

Ratnaningsih, A. (2017). Ibu pintar asuh anak: Mengasuh anak tanpa stres usia 0-5 tahun.Cemerlang.

https://books.google.co.id/books/about/Ibu_pintar_asuh_anak.html?id=5s 0TuAEACAAJ\&redir_esc $=y$

Sujiono, Y. (2009). Konsep Dasar Pendidikan Anak Usia Dini. PT indeks.

Suryawan, A. (2012). UK Tumbuh Kembang Anak dan Remaja IDAI Jawa Timur: Deteksi Dini Tanda dan Gejala Penyimpangan Pertumbuhan dan Perkembangan Anak. IDAI Jawa Timur, Surabaya.

Sutarto, A. (2006). Becoming a true Javanese: A Javanese view of attempts at Javanisation. Indonesia and the Malay World, 34(98), 39-53. https://doi.org/10.1080/13639810600650893

Warsito, O., Khomsan, A., Hernawati, N., \& Anwar, F. (2012). Relationship between nutritional status, psychosocial stimulation, and cognitive development in pre-school children in Indonesia. Nutrition Research and Practice, 6(5), 451. https://doi.org/10.4162/nrp.2012.6.5.451

Wulansari, N. (2013). WUJUD DAN FUNGSI ALIH KODE PENUMPANG DAN AWAK BUS TRAYEK JEPARA-SEMARANG (KAJIAN SOSIOLINGUISTIK). SULUK INDO, 2(3), 26-45. 